\title{
English Compound Adjective with Special Reference to Tourism Website
}

\author{
Ni Luh Rara Tian Anyar Sari \\ English Department, Faculty of Arts, Udayana University \\ [raratianyar@gmail.com]
}

\begin{abstract}
The study entitled English Compound Adjective with Special Reference to Tourism Website aims to analyze the constructions of compound adjectives found in Tourism website, explaining their syntactic functions and meaning. The data were taken from several tourism websites on internet, they are, Discover Hong Kong, Wonderful Indonesia, Italian Tourism Official Website, and Visit the USA. Firstly, the tourism websites were accessed and website pages were printed. Secondly, the website pages that had been printed were carefully read in order to find out the compound adjective. Thirdly, the relevant data on the print out were marked and phrase containing the data were noted. Then, the data were listed according to its right-hand component of compound. The data were analyzed based on the theories adopted in this study. The grand theory used is the theory of word-formation proposed by Bauer (1983) to analyze the construction of compound adjective. Meanwhile, theory of syntactic function proposed by Quirk and theory of meaning developed by Palmer were used as the supporting theories. The findings reveal that there are five patterns constructing the compound adjectives in tourism website being analyzed; they are: noun + adjective, adjective + adjective, adverb + adjective, noun + noun, and adjective + noun. The compound adjectives found mostly have attributive functions in which the compound adjective pre-modifies the noun. Moreover, most of the compound adjectives found are transparent in their meaning, which is easily determined from the constituents that construct the compound adjectives.
\end{abstract}

Keywords: compound, adjective, construction

\begin{abstract}
Abstrak
Penelitian dengan judul Compound Adjective with Special Reference to Tourism Website bertujuan untuk menganalisis konstruksi kata sifat majemuk yang ditemukan dalam website pariwisata, menjelaskan fungsi sintaksis beserta arti yang terkandung dalam kata sifat majemuk. Data penelitian ini diambil dari beberapa website pariwisata, yaitu Discover Hong Kong, Wonderful Indonesia, Italian Tourism Official Website, and Visit the USA. Pertama, website pariwisata diakses dan halaman website dicetak. Kedua, cetakan halaman website dibaca dengan seksama untuk mendapatkan kata sifat majemuk. Ketiga, data yang relevan ditandai dan frasa yang mengandung kata sifat majemuk dicatat. Selanjutnya, data didaftar sesuai dengan komponen kanan dari kata sifat majemuk. Data dianalisis menggunakan teori utama yaitu teori wordformation yang dikemukakan oleh Bauer (1983) untuk menganalisa konstruksi kata sifat majemuk. Sedangkan, teori fungsi sintaksis yang dikemukakan Quirk dan teori makna yang dikembangkan oleh Palmer digunakan sebagai teori pendukung. Hasil analisis menunjukkan bahwa ada lima pola yang mengkonstruksi kata sifat majemuk dalam
\end{abstract}


website pariwisata yang dianalisis yaitu, kata benda + kata sifat, kata sifat + kata sifat, kata keterangan + kata sifat, kata benda + kata benda, dan kata sifat + kata benda . Sebagian besar kata sifat majemuk yang ditemukan memiliki fungsi atributif yang mana kata sifat majemuk mempra-modifikasi kata benda. Selain itu, kata sifat majemuk yang ditemukan memiliki makna jelas (transparan) sehingga maknanya dengan mudah dapat ditentukan dari konstituen yang membangun kata sifat majemuk tersebut.

Kata kunci: kata majemuk, kata sifat, konstruksi

\section{Background of the Study}

One of the most productive ways of forming new words in English is compounding. Compounding is the process of putting words together to build a new one that does not denote two things, but one and that is pronounced as one unit. It consists of combining words having their own lexical meaning (having a substantial meaning of their own) to produce a new unit that functions as a single word. (Wisniewski: 2007).

According to Bauer (1983), there are four kinds of compound based on the classes of the elements of the compound; they are compound noun, compound verb, compound adjective, and compound adverb. A compound adjective is an adjective made up of two or more parts that act as a single idea to modify a noun e.g. a part-time employee, a high-speed chase. It is usually written with a hyphen if it is put before a noun, e.g. welldressed, never-ending and shockingpink, and pronounces both parts with equal stress. The meaning is usually clear from the words it combines. The second part of the adjective is frequently a present or past participle (O'Dell: 2001).

This study intends to analyze the construction and syntactic function of compound adjective in tourism website. Moreover, in order to understand the meaning conveyed in compound adjective, this study also tries to describe the meaning of compound adjective found in some tourism website.

Tourism website is widely used to promote and give information about tourist attraction, tourism service and product. A website is online and accessible 24 hours a day, every day of the year. Because of this, the customers and potential customers can visit tourism service provider site for information about new and upcoming products and services whenever it is convenient for them.

One way of promoting tourism product, the service providers adapt language to their own use in which they take compound words and use them as adjectives. These compounds often later become widely used in normal situations. Examples of these compounds which have become part of the English language are top-quality, economy-size, chocolateflavored, feather-light and longer-lasting.

This study is significance of understanding the compound adjective in tourism website in purpose of giving information and advertising. This study is helpful to the reader to find out the syntactic function, the construction of compound adjective and the meaning conveyed. Moreover, this study helps the reader to differentiate between compound adjective and phrase.

\section{Problems of the Study}

a) How are compound adjectives found in tourism website constructed?

b) What are the syntactic functions of compound adjective found in tourism website?

c) What meanings are expressed by compound adjective found in tourism website? 


\section{Aims of the Study}

a) To identify the construction of compound adjective found in Tourism website.

b) To explain the syntactic functions of compound adjective found in Tourism website.

c) To analyze and describe the types of meanings of compound adjective found in tourism website.

\section{Research method}

The research method of this study includes the data source, method and technique of collecting data, method and technique of analyzing data, and also method and technique of presenting data. Each part of research method is explained further in the following section.

\subsection{Data source}

This study uses digital text as the data source. The data of this study were taken from several tourism websites on the internet; they are, Discover Hong Kong, Wonderful Indonesia, Italian Tourism Official Website, and Visit the USA. There were four articles taken from each website used as the data source of this research. The articles in those websites were chosen because they contain a lot of compound adjectives with various construction patterns.

\subsection{Method and technique of collecting data}

The method of collecting data used in this study was documentation method. Documentation method was used to obtain the data from written material (tourism website). Note taking technique was applied in order to mark down the relevant data for the study.

There are several stages in order to collect the data. Firstly, the tourism websites were accessed and website pages were printed. Secondly, the website pages that had been printed were carefully read in order to find out the compound adjectives. Thirdly, the relevant data on the print out was marked and phrase containing the data was noted. Then, the data were listed according to its right-hand element of the compound adjective in order to make it easier to be analyzed. The data were analyzed based on the theories adopted in this study.

\subsection{Method and technique of analyzing data}

The data of the study were qualitatively analyzed. Qualitative means that the data is analyzed by using deep explanation or description and not involving measurement or statistics. This study applied triangulation technique. The data collected was checked and rechecked whether the data were valid or not, then doing cross-check on the data through some theories.

First, the data that had been listed according to its right-hand component were identified according to the construction of compound adjective using the theory of word-formation proposed by Bauer (1983). And then, the syntactic function of the data was explained using the theory of syntactic function of adjective proposed by Quirk, et al (1973). After that, the meaning of the data was described using the theory of meaning developed by Palmer (1984).

\subsection{Method and technique of presenting analysis}

The analysis of this study was presented both in formal and informal methods. In the informal method, each problem in this study was presented narratively in order to make the analysis understood easily. In addition, this study also applied the formal method in which the analysis was supported with three diagrams to clearly describe the syntactic function of compound adjectives. 


\section{Results and discussions}

There are several patterns found on tourist website constructing compound adjective. The construction patterns of compound adjective are categorized according to the right-hand element of the compound, adjective and noun. The analysis of compound adjective constructions is explained as follows:

\subsection{Adjective as right-hand element of the compound}

There are three construction patterns which have adjectives as their right-hand elements; they are, noun + adjective, adjective + adjective and adverb + adjective as presented below:

a. Noun + Adjective

[5-1] Leopard-like (the zebra shark with leopard-like spots)

(www.discoverhongkong.com)

This compound adjective is constructed by combining a noun and an adjective and can be considered endocentric compound, in which one member function as the head and other as its modifier. The adjective in this construction is the head of the compound and the noun acts as the modifier. This construction of compound adjective is used for expressing similarity. Leopardlike in 'the zebra shark with leopard-like spots' gives description of how the spots look.

On the data analyzed is also found compound adjective formed by noun + participle, for instance:

[5-2] Gravity-defying (the gravitydefying Iron Wing)

(www.discoverhongkong.com)

[5-3] Tailor-made (Nevada's landscape and culture are tailor-made for cowboys) (www.visittheusa.com)

Noun + participle is one of the construction patterns that is frequently found on data analyzed. This pattern of compound construction is not specifically mentioned by Bauer (1983) on his list of pattern of compound because he categorizes a participle as an adjective.

Typically, noun phrase which is containing this kind of compound adjective can be analyzed as shortened sentences with the structure of subject verb - object. The head of the noun phrase would be mostly a subject and agent, action initiator, in a possible transformation. For example, the compound adjective gravity-defying in 'the gravity-defying Iron Wing' can be transformed into 'the Iron Wing is defying the gravity'.

However, this structure cannot be applied in compound adjective taylormade in example [5-3] that has opaque meaning in which the meaning cannot be determined from the constituents of compound.

From the data observed, compound adjective with this pattern is used in attributive and predicative position. However, this compound tends to be used attributively. Compound adjective in [51] and [5-2] are used on attributive position. They have a role as premodifiers of the head of the noun phrase. Whereas, compound adjective in [5-3] has predicative function to modify the noun phrase that appears before the compound adjective which is connected with the linking verb are. The syntactic function can be understood from the diagram below:

Diagram 1:

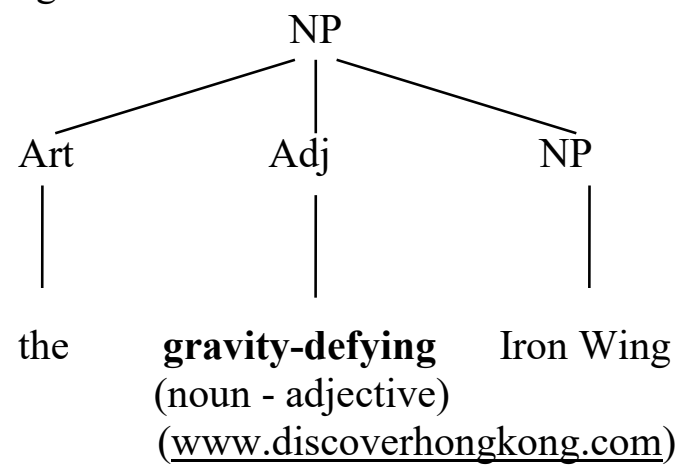


Diagram 2:

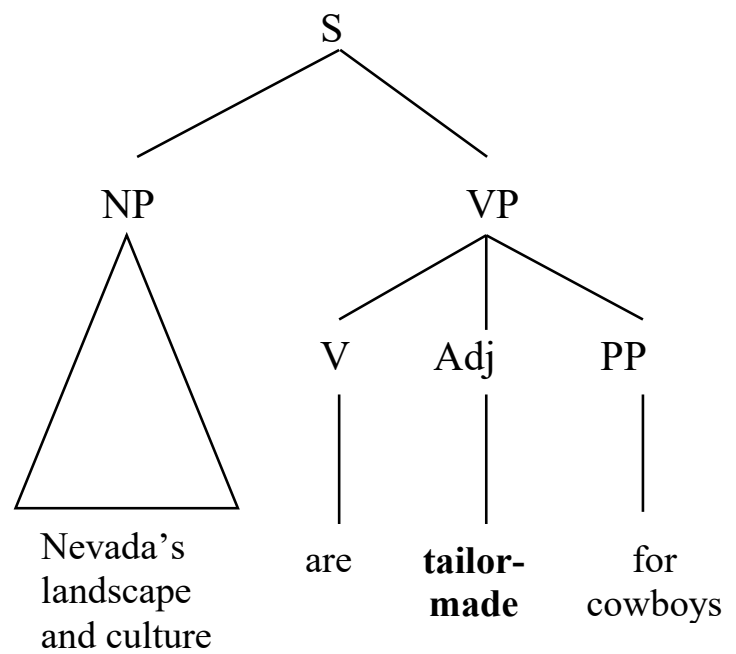

(noun-adjective)

(www.visittheusa.com)

\section{b. Adjective + adjective}

This compound adjective is constructed by attaching two adjectives. Bauer (1983) has divided this compound into two semantic groups, namely oppositional and endocentric compound adjectives. Oppositional compound is a compound in which both elements have the equal lexical status and none of the constituent lexical elements have modifying function. Moreover, eendocentric compound is a compound in which one of the lexical elements is a head and second element is dependant.

[5-4] Wide-open (wide-open spaces) (www.visittheusa.com)

Wide-open is an example of endocentric compound. The first element (wide) has got intensifying function of the second element (open).

The compound adjective formed by adjective + adjective also comes up with participle, either present participle or past participle as the second element, as in the examples below:

[5-5] Warm-inviting (Warm-
inviting waters)
(www.indonesia.travel)

[5-6] Hard-pressed (I was hardpressed to make a decision)

(www.visittheusa.com)

This compound adjective has an adjective as a left-hand constituent and a participle as right hand constituent. Bauer (1983), again, does not mention this construction pattern, but he includes this pattern into adjective-adjective compound construction.

A noun phrase containing such compound adjective can be transformed into a clause where the head of noun phrase becomes a subject, an agent and thus initiator of an action (Ptáčková: 2008). The possible sentence pattern would have subject - verb - adverbial structure, as warm-inviting in 'warminviting water', which is a combination of an adjective and a present participle. It can be transformed into 'water which invite warmly'. 'Warm-inviting water' is a metaphorical expression which is personification. Invite warmly which is actually a quality of a person instead it is used to describe noun water.

Apart from present and past participle, there is also found noun -ed as the second element in adjective + adjective compound.

[5-7] Long-tusked (long-tusked Pacific walruses)

(www.discoverhongkong.com)

The right-hand element which is a noun ending in -ed may look like a participle but in fact it is not, because in order to be a participle, the root has to be a verb, not a noun. The -ed suffix is added to a noun in order to make it become an adjective (Bauer:1983).

In case of the syntactic function, this compound adjective can be used attributively and predicatively. The compound adjective hard-pressed is used predicatively in which it appears after 
noun $I$ and modifies it. It is connected with the linking verb was.

c. Adverb + adjective

[5-8] All-new (the all-new 'Iron Man Experience')

(www.discoverhongkong.com)

[5-9] Well- known (the Asiago Plateau is well-known for its cheese)

(www.italia.it)

This kind of compound adjective is categorized into endocentric compound. An adverb word-form modifies an adjective word-form, as in [5-8]. According to Oxford Dictionary, all in all-round is categorized in word class of adverb. The adverb all modifies the adjective new. Therefore, the meaning of these compound adjectives can be easily determined from the meaning of compound constituents.

In the data analysed, this construction of compound adjective is used both attributive and predicative position. The compound adjective in [5$8]$ is used attributively to pre-modify the noun, while on [5-9] the compound is used to post-modify the noun.

\subsection{Noun as right-hand element of the compound}

It is also found that noun as righthand element of the compound as presented below:

a. Noun + noun

[5-10] World-class (a world-class infrastructure system)

(www.discoverhongkong.com)

[5-11] Home-style (Texas home-style side dishes)

(www.visittheusa.com)

Compound adjective constructed by noun + noun is only a few found on the data analyzed. According to Bauer (1983), noun compound functioning as a modifier to another noun is probably not so much functioning as an adjective as forming a three term noun compound become institutionalized and lexicalized as units, independent of their constituent part and in some cases they have different connotation from the same forms used as non-attributive compound nouns. This kind of compound adjective is exocentric compound in which the constituent has no head and the lexical category of the compound is not determined by any of the constituents.

The word class constructing these compounds may lead to conclusion that they should be considered compound nouns rather than compound adjectives. However, since this compound is put in a noun phrase to modify the head of the noun phrase then this compound is an adjective. For example, the compound adjective world-class in 'a world-class infrastructure system' is already commonly used as an adjective. According to Merriam-Webster Dictionary, world-class is considered adjective which means among the best in the world.

The syntactic function of noun + noun compound adjective found on the data analyzed is attributive. It can be understood from data [5-10], the compound adjective world-class occurs before noun phrase infrastructure system to modify it.

b. Adjective + noun

[5-12] Hot-air (a hot-air balloon) (www.italia.it)

[5-13] High-speed (a high-speed and energetic classic)

(www.discoverhongkong.com)

This compound adjective is constructed by attaching an adjective and a noun. This construction of compound is quite productive and often appears on the data analyzed. The most of these compounds are not compounds, unless 
they are used attributively, they are actually nouns. They change their stress pattern (orthographically becoming hyphenated, although this is not a trustworthy criterion) when they are used attributively (Bauer: 1983).

Since these compounds are put in a noun phrase to modify the head of the noun phrase then this compound can be considered an adjective. In a noun phrase, this compound is usually used as a premodifier, as hot-air in 'a hot-air balloon' in which it is commonly perceived as adjectival.

Furthermore, those compound adjectives are used attributively on the data analysed. Those compound adjectives have function as pre-modifier in which it modifies noun that comes after it. The compound adjective remoteisland has a role as pre-modifier to the noun experience.

\section{Conclusions}

Based on the foregoing analysis and discussion, the following points can be drawn as conclusion:

There are five patterns constructing compound adjectives found in tourism website analysed; they are: noun + adjective, adjective + adjective, adverb + adjective, noun + noun, and adjective + noun. Compound adjective constructed of noun + adjective the most frequent construction found on the data analysed. The adjective + noun construction is mainly used to express similarity of two different objects and also, to compare and specify a certain degree of the quality expressed by adjectival head. This construction is also used in order to shorten a sentence with structure of subject - verb - object.

Compound adjective found mostly has attributive function. Compound adjective is commonly used as premodifier in order to modify a noun that comes after it. Only a few of them has predicative function. Adjective phrase is more commonly used in predicative position in the data analysed rather than compound adjective. None of the compound adjective has postpositive function since a phrase will be sound unnatural.

Most of the compound adjectives found in the data is transparent in their meaning. The meaning of the compound can be predicted from the components that construct the compound. Meanwhile, the compound adjective with opaque meaning in which the meaning cannot be determined from the constituent that construct the compound is limited found in the data.

\section{References}

Bauer, Laurie. (1983). English Wordformation. Cambridge University Press, Cambridge.

Bauer, Laurie. (1988). Introducing Linguistic Morphology. Edinburgh University Press, Edinburgh.

Conti, Sara. (2006). Compound Adjectives in English (Ph.D Thesis). University of Pisa, Italy

Hornby, A. S. (2010). Oxford Advanced Learner's Dictionary. Oxford University Press Inc, New York.

Merriam-Webster.com. (2017). Merriam-Webster Online Dictionary. Retrieved September 20, 2017, from https://www.merriamwebster.com/dictionary

O’Dell, Michael M.F. (2001). English Vocabulary in Use Upperintermediate. Cambridge University Press, Cambridge. 
Palmer, F.R. (1981). Semantics.

Cambridge University Press,

Cambridge.

Ptáčková, Eva. (2008). Compound Adjectives in Women's Lifestyle Magazines (thesis). Masaryk University, Italy.

Wisniewski, Kamil. (2007). Word Formation Processes: How New Words Develop in the English language. Blackwell, New York. 